\title{
BIOPSIKOSOSIAL-SPRITUAL IMPACTS OF SEXUAL ABUSE FOR MINORS IN AMBON CITY
}

\author{
David Marthen Salakory, Jeane A. Latumahina and Blasius Retanubun \\ Department of Social Welfare, Faculty of Social and Political Science, Universitas Kristen Indonesia \\ Maluku (UKIM), Jl. Ot Pattimaipauw Talake, Kecamatan Nusaniwe, Kota Ambon \\ Email: nauluambon@gmail.com; marthensalakory17@gmail.com
}

\begin{abstract}
Sexual abuse against minors is already one of the social ills in people's lives. Victims of sexual abuse are often exposed in the public and even closed. The victim feels that it is something taboo and can even damage a person's disgrace. Therefore, they need treatment from institutions that are concerned with social issues that deal with child victims of sexual abuse. This research aimed specifically to determine the impact of the case on child victims of sexual abuse through a biopsychosocial-spiritual approach and to explain the strategy model of psychosocial-spiritual treatment, together with institutional accompaniment, referring children to doctors and being accepted by children of victims of social abuse under age. The method used in this research was a qualitative descriptive study with the type of case study. The study was carried out at the Ambon City Women's Empowerment Circle (LAPPAN). Data collection was carried out by in-depth interviews and direct observations to the victims in the field and LAPPAN officials. This research shows that victims of sexual abuse occur in underage children in Ambon City aged 9 -12 and 13 -16, which have an impact on biopsychosocial-spiritual. The psychological impact is that the child feels mentally disturbed, while the social impact is related to the child's relationship in the social environment, both at home and school. The spiritual impact makes children embarrassed to attend worship meetings in places of worship. In addition, LAPPAN provided serious assistance in reducing the psychological problems experienced by the victims.
\end{abstract}

Keywords: children; sexual abuse; minors

\section{DAMPAK PELECEHAN SOSIAL TERHADAP BIOPSIKOSOSIAL SPIRITUAL BAGI ANAK DI BAWAH UMUR DI KOTA AMBON}

\begin{abstract}
ABSTRAK. Pelecehan seksual terhadap anak di bawah umur sudah merupakan salah satu penyakit sosial dalam kehidupan masyarakat. Korban pelecehan pelecahan seksual sering di ekspos di ranah publik bahkan tertutup, hal ini karena korban merasa sesuatu hal tabu dan bahkan bisa merusak aib seseorang. Oleh karena itu mereka membutuhkan penanganan dari lembaga yang peduli dengan masalah sosial yang menangani anak korban pelecehan seksual. Penelitian ini bertujuan secara khusus untuk mengetahui dampak kasus terhadap anak korban pelecehan seksual melalui pendekatan biopsikososial- spiritual dan menjelaskan strategi model penanganan psikososial-spiritual,bersama dengan pendampingan lembaga, merujuk anak ke dokter dan diterima oleh anak korban pelecehan sosial di bawah umur. Metode yang digunakan pada penelitian ini berupa studi deskriptif kualitatif dengan tipe studi kasus. Penelitian dilaksanakan di lembaga Lingkar Pemberdayaan Perempuan dan Anak (LAPPAN) Kota Ambon, Provinsi Maluku. Pengumpulan data dilakukan dengan wawancara mendalam dan pengamatan langsung ke lapangan terhadap korban dan pengurus LAPPAN. Hasil penelitian menunjukan bahwa korban pelecehan seksual terjadi pada anak dibawah umur di Kota Ambon berada berusia 9 -12 dan 13 -16 yang berdampak pada biopsikososial-spiritual. Dampak psikologi yakni anak merasa terganggu secara batiniah, sementara dampak sosial berkaitan dengan relasi anak di lingkungan sosial baik di rumah maupun di sekolah. Dampak spriritual membuat anak menjadi malu untuk mengikuti pertemuan ibadah di tempat ibadah. Selain itu Pihak LAPPAN melakukan pendampingan yang serius mengurangi permasalahan psikologi yang alami oleh korban.
\end{abstract}

Kata kunci: anak; pelecahan seksual; di bawah umur

\section{INTRODUCTION}

Children are blessings of offspring bestowed by God in a family. Therefore, dignity is attached in a childas a whole human being (Cloete, 2015). Children are young shoots, potentials and future generations of the nation's ideals of struggle that have a very strategic role to change the situation in their social environment and have special characteristics and traits that guarantee the continued existence of the nation state in the future (Livingstone \& Third, 2017). The presence of a child in a family is a high expectation for a married couple. Children are gold for a mother, who must strive to maintain and care from when he was still in the womb to maturity. There is the results of a study in a documentary on a case in Negeria where a Dutch woman who spends time looking for financial solutions to protect children from being malnourished and mentally deficient (Ypeij, 2010). Parents feel afraid when the child's health is disrupted and even lose the child from the family side. Therefore, parents try to keep maintaining and looking for permanent solutions so that children stay healthy always.

Facts on the field prove that child very often gets a less civilized treatment from people who 
are not responsible for sexual abuse. Ironically, the perpetrators come from the closest parties to the children themselves, such as those in the family environment, neighboring homes, even in the school environment. Therefore, schools that have a mission to prepare young golden genes have been transformed by certain people into arenas of battle for interests and power struggles (Martono, 2019). In Indonesia, the sexual abuse of minors is of particular concern by the Child Protection Commission (KPA). However, in some regions outside Indonesia, it is considered a normal and a myth because it is the child's pleasure in getting to know the environment (Cromer \& Goldsmith, 2010). The results of research in several countries in the world through the data of the Nations Development Fund for Women (UNIFEM), explained that the high sexual abuse of children that occurs in the social environment of the community require serious handling by related parties. On average $40-50 \%$ of women in the European Union region and $30-40 \%$ of women in Japan, Malaysia, the Philippines and South Korea whose activities work, which reported having experienced mental violence in the form of sexual harassment at work. In the USA, it is reported that more than $80 \%$ of adolescent girls aged 12-16 years through in-depth interviews confessed shamefully having experienced sexual abuse at school. In 2016,through a survey in Indonesia, 25,213 respondents gave information that they experienced verbal abuse as much as $58 \%$, physical actions as much as $25 \%$, watching porn to watch the activities of artist as much as $20 \%$ and had experienced rape as much as 6\% (Priherdityo, 2016). The results of the study in Ambon City showed the same thing; where in 2016, the Ambon Island Police and the Lease Islands handled 28 cases of violations against women and children (Kompas.com, 2016). In 2019, during January-March, violence against women and children were 49 cases (Kompas.com, 2019). In October, the police arrested sexual abuser of children under the age of 13 (Siwalima, 2019).

Basically, a child requires the attention of parents with extra vigilance, especially in school-age children who do a lot of activities outside the home (Coates \& Pimlott-Wilson, 2019). Minors who are victims of sexual harassment are involved in two different situations, which are uncomfortable and unpleasant (Jones, Finkelhor, \& Beckwith, 2010) where being a victim of an unethical treatment that is very painful (Okechukwu, Souza, Davis, $\&$ de Castro, 2014). The problem of sexual abuse experienced by minors in general has not received serious attention from various parties. This can be seen by the presence of sexual abuse actcommitted.

Cases of sexual harassment and violations of children's rights are often lack of public attention.In addition to data and reports about sexual abuse are barely non-existent, cases of sexual harassment or violence are often wrapped up in the community's habit that establishesthis problem as an internal family problem, and not suitable or taboo to be exposed. However, cases of sexual abuse involving individuals as well as groups have begun to get a lot of attention from the public and are interesting to be the main topic in the media. Cases of sexual abuse of women and children continue to receive serious attention and treatment. Therefore, one of the social foundations in Ambon City, which deals with sexual harassment, is doing a variety of tasks to protect and provide services to victims of sexual abuse of minors. This foundation has the name of the Ambon Women and Children Empowerment Circle (LAPPAN).

Ambon LAPPAN, once released data on child sexual abuse in Maluku Province, in 2014 as many as 39 cases. The number increased in 2015 to 46 cases and most victims of sexual abuse or sexual violence were teenage girl who were students at the elementary, junior high and senior high school levels. (LAPPAN Foundation Report, 2016). Ambon LAPPAN data shows that cases of sexual abuse against minors continue to increase from year to year. Children who are victims of sexual abuse experience various impacts in their lives, for example psychological and social impacts. Psychological impacts include depression, anxiety, post-traumatic stress disorder, behavioral disorders, and committing stupid acts such as suicide. Some examples of the post-traumatic effects of sexual harassment include nightmares, flashbacks, fear problems, and nervousness and irritability (Spataro et al, 2004; Samms \& Cholewa, 2014;). Another psychological impact is that they can change their perception of themselves by seeing themselves as insignificant and devoid of self-worth. The social impact faced by children is that children's relationships are limited, because they feel that they are no longer valuable. Children feel a lack of social and emotional support which makes them unacceptable in their social environment. The social environment has given a special label for children, so that they are increasingly embarrassed to establish communication and socialization with their family members at home or in the community. Children no longer enjoy the social environment that can make themselves part of it, but always feel judged, restrained, and even rejected (Sulastri, 2019).

Thus, the purpose of this study was specifically to determine the impact of cases on child victims of sexual abuse through a biopsychosocialspiritual approach and to know the strategy model of psychosocial-spiritual handling, along with institutional accompaniment, referring children to doctors and being accepted by minors of social abuse 
victims. Considering this, this study further explored the situation of minors who experience sexual abuse incidents handled by the Ambon Women and Children Empowerment Circle Foundation (LAPPAN).

\section{METHOD}

This study used a qualitative descriptive research method with the type of case study. It aimed to understand a phenomenon in the social context naturally by promoting the process of deep communication interaction. Thus, this research approach sought to deepen the phenomenon of the examined human problem. the qualitative method is a research procedure that produces descriptive data. This approach makes a description of the presentation of data through words, which are expressed in detail from the informants, on the concrete situation experienced (Creswell, 2014). Qualitative research has two main objectives, the first is to describe and to exploreand the second to describe and explain.

The location of this research was carried out at the Women and Children Empowerment Foundation (LAPPAN) in Ambon City, Sirimau Sub-District, Air Besar Karang Panjang. This foundation has the duty to help overcome the problems of children and women who are victims of sexual harassment and violence.

The main instrument in qualitative research was the researcher. Thus, in this study the researcher acted as one of the key instruments. The collection technique was in the form of an interview guide containing questions that have been designed to obtain the expected data from both the victims and the LAPPAN foundation. The questionnaire instrument was also carried out to find forms of acts of abuse perpetrated by perpetrators and victims. In addition, the foundation filled out questionnaire data to find out the handling that was done. Documentary evidence was in the form of a study conducted by LAPPAN a few years ago related to sexual abuse and LAPPAN activities during the handling of victims with medical parties, psychologists and even religious leaders. The data sources were informants as victims that consisted of 5 children, and 3 other informants, namely 1 leader of the institution, and 2 employees who function as victims' assistants. Data analysis techniques used in this study were based on, expressing four stages of data analysis techniques, namely 1) data collection; 2) data reduction; 3 ) data presentation and 4) verification and inference (Miles \& Huberman, 1994).

\section{RESULT AND DISCUSSION}

\section{Characteristics of Informants} Age

The existence of employees in Ambon LAPPAN is certainly very important and determines the direction and objectives of the institution. The condition of employees here is related to the total number of employees, 9 people, with age groups ranging from $23-58$ years with details of 1 male and 8 female. While the management of the LAPPAN Foundation only has a management of 2 people, namely the Chairperson of the Foundation who is also an ex officio Director / institution leader and another person. The detail isshown in Table 1.

Table 1. State of LAPPAN Ambon Foundation and Staff

\begin{tabular}{ccccc}
\hline $\begin{array}{c}\text { Management } \\
\text { and Staff }\end{array}$ & Age group & Total & $\begin{array}{c}\text { Gender } \\
\mathrm{M} / \mathrm{F}\end{array}$ & $\begin{array}{c}\text { Religion } \\
\mathrm{C} / \mathrm{I}\end{array}$ \\
\hline $\begin{array}{c}\text { Foundation } \\
\text { Managers }\end{array}$ & $\begin{array}{c}30-49 \\
\text { years }\end{array}$ & 2 & $\mathrm{~F} / 2$ & $\mathrm{I} / 2$ \\
Institution & $23-58$ & 9 & $\mathrm{~F} / 8$ & $\mathrm{I} / 5$ \\
employees & years & & $\mathrm{M} / 1$ & $\mathrm{C} / 4$ \\
& Total & 11 & 11 & 11 \\
\hline
\end{tabular}

\section{Institutional Programs and Services}

The Ambon LAPPAN Foundation has a community service program, which in its development focuses its service on handling five program issues, namely: 1) Prevention and handling of Abuse and Violence (sexual) Based on Gender (PKBG)on a cross-island community basis; 2) Strengthening and promoting sustainable peace through community children's forums and the establishment of PAUD (preschool) focusing on diversity issues; 3) Promotion of maternal and children health rights; 4) Empowering the family economy based on regional potential; 5) Building a perspective on natural disaster prevention.

Based on the LAPPAN service program above, program No. 1. isPrevention and handling of Abuse and Violence (sexual) based onGender (PKBG) on cross-island communities, specifically dealing with children who experience sexual harassment / violence.

\section{Characteristics of Informants by Education Level and Age Group}

Table 2. Condition of Education and Age of Children of Sexual AbuseVictims

\begin{tabular}{cccc}
\hline Level of education & Age group & Total & Percentage \\
\hline $\begin{array}{c}\text { Elementary School (SD) } \\
\text { Junior High School } \\
\text { (SMP) }\end{array}$ & $9-12$ years & 2 people & 40 \\
\hline 13-16 years & 3 people & 60 \\
\hline Total & 5 people & 100 \\
\hline
\end{tabular}

Based on table 2, it shows that the informants of the 9-12 years age group are 2 people, and the age group 13-16 years are 3 people. They are victims of sexual abuse of minors who are victims of sexual abuse or violence with a percentage of $40 \%$ are children who while in elementary school with the initials (AW) and $(\mathrm{N})$. and the percentage of 
$60 \%$ is in junior high school with the initials $(\mathrm{AH})$, (LP), (VU). Data were collected from the results of handling cases of sexual violence, from the context of the event occurred together with minorswho were still in elementary and junior high school as many as 5 acts of sexual abuse. The action or treatment thatwas obtained by children in this sexual abuse case is "Child being forced and threatened". Children were forced to fulfill adult sexual desires. Meanwhile, the threat "Children are prohibited from saying or reporting to anyone.". The strategy used by the perpetrator was to frighten or threaten the victim.

According to (BT) the head of the LAPPAN institution, Children who experienceed acts of sexual violence in macro, the perpetrators were productive age adults between 25-57 years, with varying levels of education and professions, among others, perpetrators who only graduated from elementary school, some who did not graduate elementary school, but there were also graduated from junior high school and high school graduates, and some even still studied in tertiary education, or who had graduated from tertiary education. Furthermore, the perpetrators vary in their profession / occupation, including those who work as Civil Servants, members of the police, members of the Regional People's Representative Council (DPRD), motorcycle drivers, and some who work as Angkot (city transport) drivers. There were even actors who are unemployed, and odd workers. Most perpetrators of sexual violence against children were people close to the child, it could be her parents, stepfather, brother, uncle, relatives of parents, or neighbors.

Against Informant 1 (AH), when she was asked what kind of sexual abuse was experienced, (AH) revealed that ".... Initially, at night, the perpetrator held me, then hugged me, and then kissed me. According to $(A H$,$) the perpetrator who$ committed sexual violence against her was the husband of her father's sister. At that time, Father told me to stay with his sister because dad's sister does not have a daughter. In the house of papa's sister, there were only four children and her husband. Therefore, her father's sister misses a girl who can be a friend for the story at any time ... ". The situation experienced by (AH) was supported by $\mathbf{A R}$ that this type of sexual violence is called Familial Abuse where the perpetrator of sexual abuse / violence is a family member who lives with the children.

Informant recognition gives meaning about minors who often getunethical treatment from their own close person. As revealed by $(\mathrm{AH})$, that the perpetrator of sexual harassment was husbands of her dad's sisters. “... The incident of sexual harassmentoccurred in her aunt's house while she was sleeping. Furthermore $(A H)$, revealed thus: So it was already late at night and everyone at home was sleeping. At that time, he (the perpetrator) began to react. Hetold thereason of going to the restroom. (AH) revealed, at the beginning, I did not think to the negative. I just think he was like my own father. However, when my aunt's husband went to the restroom, then directly to my room. At that time, I was not asleep, so he opened the door and metme and closed my mouth. The next action was to do the things he wanted, he hold me and squeezed parts of my body. After that I cried and was threatened if Itoldanyone. In the morning around 05.00 CET, I immediately returned to myhome. However, when I arrived I didn't say anything negative but just told Papa and Mama that shedidn't want to live with other people....".

Sexual abuse events, if left by the victim or family or parents not to be treated, then the event or incident can be repeated again by the perpetrator against the children as victim. The recurring incident also occurred to (AH), even though the victim had returned to live in her own home. Because they have a family relationship, the perpetrators returned to the victim's home to look for victims, as the victim stated as follows. "... When I returned home while temporarily in asleep, my uncle also entered my room. At that time my parents weregoing to the garden. He went into the room and did a very embarrassing thing that was not appropriate for me for the second time. At that time, I rebelled and tried to fight, but as a girl, I had no strength. At that time, uncle threatenedher sisterwho saw the incident when she went to wash plate. That was when my sister directly went to the garden to convey to her parents. When my parents returned, I said all the things that had happened and they reported to the Village Head. Furthermore, the village authorities reported to the Waisala Police Station in SBB Regency and brought the perpetrator to the Piru Police Station. Ibu (BT) the Head of the LAPPAN Foundation who always accompanied me when I was in Piru (downtown of SBB Regency). My uncle as the perpetrator was detained for 2 months and processed for trial to be put in prison.

Sexual violence against children is not only done by close people in the family who live in the same house as experienced cases (AH), but also close people such as neighbors. The case that happened to Informant 2 (LP) for example, was bad treatment by her neighbor's house. As a neighbor who lived close together, (LP) lived with her father and mother with 3 siblings, 2 female and one male, from a background of poor parents. Her father worked as a car driver and mother was only at home. (LP) was the first child to be sexually assaulted by a 22-year-old man in a neighboring house. The incident occurred in an empty house, when (LP) went to the home of a school friend.

Based on the results of the interview with the victim (LP), information was obtained that while 
studying with her friends, there was a man who always followed her. The man finally chases the victim using black magic so that the victim falls in love with the perpetrator. One time the victim was spending the night at his friend's house, the perpetrator came noisily calling the victim and her friend. Without asking, the victim came out of her friend's house, then the perpetrator immediately took him to an empty house adjacent to his friend's house. The victim had rebelled and hit the perpetrator, but the victim was not strong enough to save herself. Finally, the perpetrator immediately committed the atrocity. The victim's friend came with his parents to take the victim, but the scene of the crime was over.

Acts that occur against (LP) are abuse in the form of coercion to the victim, sexual violence by coercion of sexual relations carried out because there is an intention from the perpetrator to the victim, which the perpetrator had planned and the perpetrator dared to do it while drunk. In fact, the perpetrator also threatened the victim thatif she told the incident the victim would be killed.

There was an attempt to fight back, but the victim was unable, finally the victim gave up and the incident happened, which in turn the victim did not want to continue their education to senior high schoolafter graduating from junior high school. Fortunately, there was assistance from the LAPPAN Institute through (BT), which means the head of the Foundation and the companion of the institution to the victim, namely (Mama Jo), who had committed to the victim to take care of the victims completing education in high school. The problem of sexual violence was finally reported by the LAPPAN Institute to the police for the perpetrators to be detained, until it was handled in court trials. Responding to the court's decision, the perpetrator's family asked the victim's family to solve the problem throughfamily way, but the father of the victim's family did not want to, because he was very shocked, stressed by the events experienced by her child. The event of this sexual violence occurred due to the act of coercion of sexual relations. All of these actions must have the intention of the perpetrator to the victim with a plan whose motives must be drunk, so that the perpetrators dare to dohis intentions. The coercive attitude towards the victim is always followed by threatening behavior, shouting to kill the victim, so as not to inform others.

Judging from the events of sexual abuse that occurred in (AH), (LP), (AW), (VU), and (N), the 5 informants gave answers that the perpetrators had similar behavioral characteristics. The behavior displayed by the perpetrators is abuse and violence in the same context in their actions. It distinguishes only from single perpetrators who commit sexual violence themselves, and there are also those who commit harassment / violence together, as experienced by the 3rd sisterr's informant (AW), who revealed that there were 4 perpetrators who were victims of sexual harassment against their younger siblings, who were 9 years old, 11 years old, 13 years old, and 14 years old.

Once again, there are similarities in the perpetrators of sexual harassment, namely that they are close people. They can be victims'family, and also neighbors, or school friends. Related to the case that happened (AW), it turns out that the perpetrator was a school friend who was close to the victim because they live next door. They were playmates everyday in the home environment. They carried out their intentions in a group by inviting victims to an empty house not far from their neighborhood. This empty house was called among the children as "Headquarters".

The victim's brother (AW) stated that the perpetrator did it by dividing the tasks. For example, someone has to tie the victim's hands and cover his mouth. The other 2 perpetrators had forced sexual intercourse with the victim, while the other 2 monitored the situation to ensure that no one had seen the crime.

When they were asked by the police why doing it to their friends, they pointed out the reason thatthey were affected by watching porn and wanted to practice it. The victim experiences violence forcing sexual relations where the child was made as an object of attempted sexual relations. Besides that, victims was threatened in order not to notify them to theirfamilies. However, LAPPAN always accompanied the victims and finally the law states the truth and justice accurately and clearly. Victims and families get legal certainty in court against perpetrators, but another problem that often arises against children who were victims of sexual violence is the environment where she lived.She felt inferior, ridiculed and insulted by people both in the home environment and in the school environment. This condition made the victim become stressed and traumatized considering the events that have happened to her.

Victims who experienced violence through forced sexual relations were also experienced by the 4th informant (VU). According to (VU), She knowthe man whowould be sex perpetrator at her girlfriend's house. Sexual violence was in the form of coercion of sexual relations by administering drugs in the victim's drink, thereby making the victim lose self-awareness and the perpetrator used the victim, committing an inappropriate action. After regaining consciousness, the victim (VU) cried hysterically because the victim's friend was no longer there. The victim immediately returned home and reported the incident to the parents. The report was followed up to 
LAPPAN to get legal assistance and psychological recovery. The perpetrator's family then took a familial approach to the solution and agreed to take responsibility, because the victim was pregnant. After giving birth the victim took care of the child, but gradually the perpetrator no longer wanted to be responsible to the victim. Finally, the victim returned to her parents, along with her child, to support her.The type of sexual harassment experienced is coercion in a different way. Specifically for (VU) by giving drugs in the victim's drink so that the victim loses self-awareness and the perpetrator made use of the victim, taking an inappropriate action on the victim.

Indeed, in the end, there was a saying that "good friends are evil enemies". This saying was used to analogize the relationship of a good colleague at the same workplace, between the father of the sexual abuse victim and his coworker. Being a good friend of the victim's child's father, the victim's mother asked her husband's friend to see her two daughters, because her mother wanted to go out for a while. It turned out that a 9-yearold girl wanted to take a pee, then asked her uncle to accompany her to the toilet. This was the beginning of cases of sexual violence. Furthermore, the mother of the victim's child (N) said as follows. "... At my husband's workplace in one of the hotels in this city, there was a place for employees' families to watch together. When we sat together, I wanted to come out for a while then I left my two daughters with the Dad's coworker of victim. At that time, my daughter who was a victim was 9 years old and her sister was 6 years old. When I left them both, I immediately left and even then only briefly. But it turns out that my 9-year-old child who was a victim felt like she wanted to pee in the toilet. Her child says tothe perpetrator thatshe wanted to pee and went to the bathroom. Then, theuncle took the child to the bathroom while her sister was in the gathering room. I just found out that afternoon when I found my child wanted to pee,she said that if her vagina hurts and he cried then I wondered to her. She finally told all the events that had happened. When she dropped her pants to pee, it turned out that he did insolence in which a 9-year-old child knew nothing and just rested in pain and crying. Her uncle said that she may nottell mama, dad or anyone. I told my husband and without a second thought my husband immediately reported the perpetrator to the police station. My daughter and I were accompanied by a companion from LAPPAN to handle my child's case until the verdict and the perpetrator was jailed for more than 5 years ... "According to the mother, the child as victim said that she felt very stressed and traumatized by what happened to her. I as her mother also could not understand why this was done for my young child. My child seemed unhappy everyday, she was depressed, like depressed, but fortunately there were LAPPAN as party that always provide assistance to direct my child as well and then to eliminate trauma, making her feel comfortable with herself and the environment.

Children as a continuation of the generation must be cared for properly, because when we neglect to pay attention to our children and handed over to others to take care of, it can happen sexual violence for them. All informants who were sources of information were girls who were victims of sexuality abuse / violence. The type of sexual harassment experienced was abuse of minors and the threat of the perpetrators to the victim not to notify the victim's parents.

When asked what were the resistance efforts made by the informant to fight, her mother said there was no resistance because at the time of the incident, she was only 9 years old, so the child did not know anything. Mother looked resigned, confused, wondering quietly seeing that. Since this problem the client and her family decided to move from Ambon and now live outside Ambon.

\section{Impact on biopsychosocial and spiritual of minors asvictims of sexual abuse}

Judging from the events of sexual abuse that occurred in children (AH), (LP), (AW), (VU), and (N), the five (5) informants gave answers that had almost the same behavioral characteristics. The behavior displayed by the perpetrators is abuseand violence in the same context in their actions. What distinguishes only the single perpetrators who commit sexual violence themselves, and there are also those who do abuse / violence together, as experienced by the 3rd informant (AW), a victim of 4 children, her own school friend aged 9,11, 13 and 14 years old.

The LAPPAN Institute's explanation of the condition of children who experience sexual abuse / violence, on average experiences an impact on the bio-psycho-social-spiritual aspects. That fact was also revealed in the results of a study of 5 girls $(\mathrm{AH})(\mathrm{LP})(\mathrm{VU})(\mathrm{AW})$ and $(\mathrm{N})$. The impact on the biological aspect is the physical health condition of the victim to be bad, due to the victim's genitals torn, they get pregnant, and are depressed. The impact of bio has a relationship with genetic anomalies, namely the nature and behavior of the disorder, feeling 
inferior or feeling insecure in the group, and in their social environment. The impact on psychological aspects is that minors who are victims of sexual abuse have prolonged traumatic experiences, namely psychological trauma, including anxiety, fear, insomnia, and nightmares (Scarpelli, Bartolacci, D'Atri, Gorgoni, \& De Gennaro, 2019). Children who are victims of sexual abuse are girls who in their admission have had a long life to go. This situation makes the victim child stressed, because of experiencing severe life problems, low self-esteem and weakened enthusiasm for life, shame to the person she encounters, fear, and mental or personality conditions feel rejected in relationships.

The impact on social aspects is that children who become victims do not want to interact and communicate because they experience feelings of rejection, shame related to the environment at home or at school. Besides that, the victim's parents do not want their children to get along, interact and communicate with others because there is a parent's concern that there will be other people mocking the child, besides that the parents prevent the events that have happened to their children from happening again.

The impact on the spiritual aspects of child victims who usually go with their parents to worship in the Church or in the Mosque, now after the victims experienced the incident they generally feel ashamed to go to worship, afraid to see others. Besides, there are parents who forbid their children from participating in religious activities. Sexual abuse and sexual violence in the form of rape are actually not just a form of violation of the law against the rights of others and classified as criminal acts, but more than that (Pathak, 2016). A sexual event that is carried out by male against female under the age of the background of the situation of sociocultural values in society that is more or less gender biased. Growth and development of children who experience problems, it is important to pay attention to the proper welfare of the spiritually, physically and socially (Manikam, 2002).

\section{Institutional Accompaniment Strategy for children of sexual abusevictims}

LAPPAN strives to bring various cases of sexual harassment to legal channels under applicable legal procedures. The mechanism starts with making a report on the police side, then it is processed to court. LAPPAN also prepares lawyers to accompany the legal process of these cases. Strategies implemented by the institution in carrying out the process of assisting families and children of victims through work procedures include: Stress and trauma healing services, legal services, legal advocacy from the preparation of police investigation reports to court trials. Thus, the work procedure of the institution through its service program according to the victim's and the victim's parents, is enough to give satisfaction to the child and family, because the institution is serious about handling the victim to obtain legal certainty in court. The handling strategy developed by the institution is the victim's right, where the victim has the right to get protection from social institutions, the police, the prosecutor's office, based on the stipulation of a protection order from the court (RI Law No. 23/2004 concerning Elimination of Domestic Violence Article 10a).

In carrying out the task of handling minors of sexual victims, the role of employees / administrators of the LAPPAN foundation is quite helpful in the service of cases of victims of sexual abuse / violence. As expressed by the Chairperson of LAPPAN (BT), that the types of cases of sexual abuse / violence against children they deal with consist of: rape, sexual abuse, sexual coercion of children, early marriage, attempted rape, and sexual exploitation.

It was further said that the handling / assistance in carrying out gender-based prevention focused on two strategies: first, making service posts at the community level, second, conducting socialization to the community generally based on religious organizations / groups, traditional institutions, and educational institutions at the elementary level, junior high school to senior high school. Strengthening prevention is also carried out through a series of campaign activities and socialization of legislation, including: the Law on the Elimination of Domestic Violence, the Law on Child Protection, and the concept of childrenfriendly. This is important because sexual abuse / violence for children is quite common in the community.

The institution also develops networks with law enforcement officials, influencing policies in the context of providing support services for child victims in the form of advocacy to build a human rights and gender perspective. One of the policy advocates at the level of Maluku Province and Ambon City was the formation of the P2TPA Integrated Service Center for Women and Children) in 2007, then followed by the Central Maluku Regional Government, West Seram Regency, and Buru Regency. In addition, to ensure the protection of women and children, LAPPAN has also succeeded in encouraging the birth of PERDA (Local Regulation) Number 2 of 2012, which guarantees legal certainty for women and children victims of sexual abuse and victims of violence. In line with the local regulation, the development of LAPPAN Institute collaboration also involved the community in the movement to eliminate abuse and violence against women and children through a 16 
day anti-abuse and violence campaign involving support groups of women and children, with full support of the government officials of Ambon City and Maluku Province.

Regarding children who were victims of sexual abuse said by the informant of institutioncompanion 1 (SW), that their conditions often experience fear when they see people, especially those who are seen to have the same characteristics as the perpetrators of sexual abuse / violence. Another thing experienced when handling child victims is the victim does not dare to speak. The victims arevery closed. The handling strategy of companion to clients is to bring the victim in a place far from her social environment, far from the views of those around her who have known her, then invite her to talk and relate to others.

To return children to understand life experiences experienced as a reality of life, then according to the institutioncompanion 2 (JP): Institutioncompanion do not provide accompaniment to child victims themselves, but the institution opens a network of cooperation with experts who have capacity in their fields. Experts who handle cases of children according to their field of work follow the results of the assessment prepared by the institution companion. Functionally, psychologists work to build up the fragile mental state of the victim's child. Religious leaders function to instill the strengthening of spiritual values of faith, fortitude to victims and parents in providing support for their children. This is very important because the situation of child victims of sexual abuse / violence is experiencing the effects of psychological trauma, such as anxiety, fear, insomnia, and nightmares (Matos \& Gonçalves, 2019). The condition of the child requires Trauma Healing by the companion of the institution to the minors victims of sexual abuse in an effort to return the child to the reality of her life.

In carrying out further assistance to the victim according to (JP): the institution provides maximum protection for victims so that victims do not feel afraid, the institution companion also care for their clients lovingly meaning to love victims like their own children, giving full attention to victims, so victims feel full institutional support protects her.

Another strategy undertaken by the agency's assistants to provide protection for the victim is that the victim is moved from her place of residence where the abuse / violence occurs, so that the victim does not recall the incident, conduct further trauma healing by inviting victims to play to the beach, walk to the Mall , it means to make the victim feel happy and not think about the incident. Furthermore according to (JP) the handling of child victims of sexual abuse who experience the impact of Biology-Psychology-Social and Spiritual?is the impact on aspects of Biology: the victim has a weak body condition because there are some pregnant victims, so that makes victims depressedand because the victim's genitals were torn too. The handling of institution companionis to provide assistance with routine pregnancy checks until hospital admission and safe delivery. On the impact of the Psychological aspects: the victim feels ashamed of the person she met, and is afraid. However, after being dealt with through psycho therapy and counseling by psychologists who are employed by the institution along with the institution companion, victims can experience recovery and be able to understand their reality, avoid embarrassment towards others and the victim's state of fear can return to normal. The impact of social aspects: victims do not want to interact and relate because of feeling rejected, and ashamed of the home or school environment. In addition, the victim's parents do not want their children to interact and relate with others because there is a concern that people will mock the victim's child, as a result the effects of events that have happened to happen again. Children in the home environment do not get along. This problem can be handled by the companion of the institution, as a result, the victim can re-interact with her home environment. On the other hand, the LAPPAN Foundation socializes the parents so that parents no longer forbid the victim to relate to other people because the victim needs interaction with others to restore social relations. Then, the Impact of Spiritual Aspects: victims in their daily lives often worship at church following their parents, after victims experience the incident, the victim is ashamed and afraid to see other people so that makes her parents forbid the victim to participate in religious activities. After being handledby the institution through the approach of religious leaders, the victim experiences a change in behavior that is initially afraid of others returning close to others and allowing victims to participate in worship activities as usual.

\section{CONCLUSION}

Through the results of the study, it was concluded that sexual abuse against minors occurs in victims who have the characteristics of ages 9-12 years and 13-16 years who are still attending elementary school and junior high school. Forms of sexual abuseare hold, touch, to sexual relations, by seducing, forcing, suppressing and threatening. Child sexual abuse impacts biopsychosocial and spiritual aspects. Children feel tortured both physically and psychologically. Physically, they have weak physical health, children feel sick, their genitalsn were torn, and get pregnancy. Psychologically, they feel ashame, stress, trauma, and interactions and relationships 
become disturbed in the social environment of children (home, school) and in relationships. Children experience the shock of faith because the are ashame to worship on the spiritual aspects. Strategies for handling victims of sexual abuse include Bio Aspects that is the companion of the institution to provide medical examination assistance by doctors prepared by the agency, routine pregnancy checks for a child who is pregnant, and admitted to the hospital until they give birth safely. The psycho aspect is doing psycho therapy and counseling by psychologists used by the institution along with the institution companion, then the victim can experience recovery and be able to face the reality. In the social aspect, the institution do socializing to parents in order not to prohibit victims from relating to others because victims are treated to be able to interact and restore their social relations. Whereas, the spiritual aspect is handled by the institution through the approach of religious leaders, through pastoral counseling, religious guidance so that it does not experience the shock of faith, but must be strong, steadfast in hopeful life. In the field of law, legal advocacy is accompanied by victims for police investigation reports to the court, for the sake of legal certainty.

The implication of the research is as a serious input to related parties including regional leaders, security forces, related agencies and religious institutions to find a good strategy to help this problem. Suggestions for further research is to develop a model for empowering sexual abuse for minors to be used by related parties in resolving sexual harassment issues.

\section{REFERENCES}

Cloete, A. (2015). Youth unemployment in South Africa: A theological reflection through the lens of human dignity. Missionalia, 43,(3), 513-525. https://doi.org/10.7832/43-3-133.

Coates, J. K., \& Pimlott-Wilson, H. (2019). Learning while playing: Children's Forest School experiences in the UK. British Educational Research Journal, 45,(1), 21-40. https://doi. org/10.1002/berj.3491

Cromer, L. D., \& Goldsmith, R. E. (2010). Sociocultural issues and child sexual abuse: Child sexual abuse myths: Attitudes, beliefs, and individual differences. Journal of Child Sexual Abuse, 19,(6), 618-647. https://doi.or g/10.1080/10538712.2010.522493.

Creswell, John W. (2014). Research Design, Qualitatives, Quantitative, and Mixed Methods Approcahes (Fourth Edition). United State of America: Sage Publications.
Jones, L. M., Finkelhor, D., \& Beckwith, J. (2010). Protecting victims' identities in press coverage of child victimization. Journalism, 11,(3), 347-367. https://doi. org/10.1177/1464884909360925.

Kompas, 2019. Kasus Kekerasan Terhadap Perempuan dan Anak di Ambon Meningkat [Cases of Violence Against Women and Children in Ambon Increases].https://regional. kompas.com/read/2019/03/09/15143861/ kasus-kekerasan-terhadap-perempuan-dananak-di-ambon-meningkat.

Lappan Ambon. Antara Maluku (2017), Kekerasan Seksual Masih Tinggi [Sexual Violence Still High], Maluku : Shavira Alaidrus.

Livingstone, S., \& Third, A. (2017). Children and young people's rights in the digital age: An emerging agenda. New Media and Society, 19,(5), 657-670. https://doi. org/10.1177/1461444816686318

Manikam, R. (2002). Mental health of children and adolescents. International Perspectives on Child and Adolescent Mental Health, 2,(C), 1-36. https://doi.org/10.1016/S18745911(02)80002-1.

Martono, N. (2019). Sekolah Inklusi Sebagai Arena Kekerasan Simbolik [The School of Inclusion as an Arena of Symbolic Violence]. Sosiohumaniora, 21,(2), 150-158. https://doi. org/10.24198/sosiohumaniora.v21i2.18557.

Matos, M., \& Gonçalves, M. (2019). Sleep and women intimate partner victimization: Prevalence, effects and good practices in health care settings. Sleep Science, 12,(1), 35-42. https://doi.org/10.5935/1984-0063.20190057.

Miles MB, Huberman AM. (1994). Qualitative Data Analysis: A source book for new methods. Thousand Oaks: Sage Publications

Okechukwu, C. A., Souza, K., Davis, K. D., \& de Castro, A. B. (2014). NIH Public Access Author Manuscript Am J Ind Med. Author manuscript; available in PMC 2015 May 01. Published in final edited form as: Am J Ind Med. 2014 May ; 57,(5): 573-586. doi:10.1002/ajim.22221. Discrimination, Harassment, Abuse and Bullying in the Wo. American Journal of Industrial Medicine, 57(5), 573-586. https:// doi.org/10.1002/ajim.22221.

Pathak, H. (2016). Beyond the Binary: Rethinking Gender Neutrality in Indian Rape Law. Asian Journal of Comparative Law, 11,(2), 367397. https://doi.org/10.1017/asjcl.2016.8. 
Priherdityo, E. (22/7/2016). Pelecehan seksual verbal dianggap lumrah di Indonesia [Verbal sexual harassment is considered normal in Indonesia]. CNN Indonesia.

Samms, K. M., \& Cholewa, B. E. (2014) Exploring the context of child sexual abuse in jamaica: addressing the deficits. Journal of Child Sexual Abuse, 23,(2), 115-127, DOI: https:// doi.org/10.1080/10538712.2014.870948.

Scarpelli, S., Bartolacci, C., D’Atri, A., Gorgoni, M., $\&$ De Gennaro, L. (2019). The functional role of dreaming in emotional processes. Frontiers in Psychology, 10,(MAR), 1-16. https://doi. org/10.3389/fpsyg.2019.00459.

Siwalima, (2019). Warga Kebun Cengeh di Ringkus Polisi [Residents of Cengeh Gardens were arrested by the police]. https://siwalimanews. com/warga-kebun-cengkeh-diringkus-polisi/.
Spataro, J., Mullen, P., Burgess, P., Wells, D., \& Moss, S. (2004). Impact of child sexual abuse on mental health: prospective study in males and females. The British Journal of Psychiatry, $84,416-421$.

Sulastri. 2019. Kekerasan Seksual Terhadap Anak: Relasi Pelaku- Korban, Pola Asuh dan Kerentanan Pada Anak [Sexual Violence Against Children: Offender-Victim Relations, Parenting and Vulnerability in Children]. Jurnal Psikologi Malahayati, 1,(2), 61-71.

United Nations Development Fund for Women. The Facts: Violence against women and Millenium Development Goals. Diunduh pada 28 Maret melalui www.endvawnow.org/ uploads/browser/ files/EVAW_FactSheet KM_2010EN. Pdf.

Ypeij, A. (2010). Mama blessing. African and Black Diaspora: An International Journal, 3,(1), 135-136. https:/doi. org $/ 10.1080 / 17528630903368208$ 